\title{
South Ndebele Language
}

National Cancer Institute

\section{Source}

National Cancer Institute. South Ndebele Language. NCI Thesaurus. Code C154046.

A Niger-Congo Bantu language spoken by the Ndebele people of South Africa. 